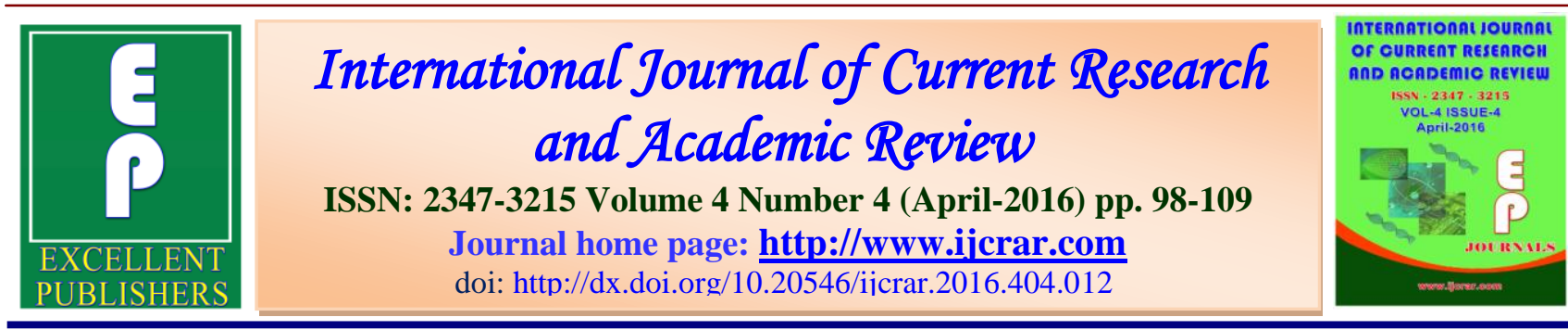

\title{
An Overview of Viral Disease on Chickpea and Impact on Chickpea Production in Iran
}

\section{Shahraeen Nooh $^{1 *}$, Ghotbi Tabassom ${ }^{1}$, Haji Yousef Tara ${ }^{1,3}$, Azadbakht Nader ${ }^{2}$ and Bananej Kaveh ${ }^{1}$}

${ }^{1}$ Plant Virus Research Department, Iranian Research Institute of Plant Protection (IRIPP), Agricultural Research Education and Extension Organization (AREEO),Tehran, Iran.

${ }^{2}$ Plant Protection Research Department, Lorestan Agricultural and Natural Resources Research Center, Agricultural Research Education and Extension Organization (AREEO)

${ }^{3}$ Islamic Azad University, College of Agriculture, Pishva Branch, Varamin, Tehran, Iran

\section{*Corresponding author}

\section{KEYWORDS}

Serology,

Viral Incidence,

Yellowing, Disease

Status,

Luteoviruses.

\section{A B S T R A C T}

Natural infection by mainly Luteovirises was investigated in chickpea (Cicer arietinum L.) in chickpea growing areas of North Western (NW) provinces of Iran. During 2015 growing season, a total of 170 selected chickpea plants with general yellowing symptoms, including foliar bronzing and stunting, reddening of leaf margins, narrow leaves, and general growth reduction were screened for infection using tissue blot immunoassay (TIBA) and DACELISA. On the basis of 170 plant samples tested, 129 were shown to be infected to at least 5 viruses. On descending order, number of infected sample positive to BLRV using specific poly and two different monoclonal antibodies were 44 (26\%) samples, 75 (44\%) by using Mab- B-2-5G4 and 89 (52\%) with Mab 4-6G6 antibodies. SbDV was positive in 56 samples (33\%), CpCSV in $29(17 \%)$, BWYV in $32(19 \%)$, and 12 samples (7\%) were shown to be infected by FBNYV (nanovirus) respectively. Luteoviruses including BLRV, CpCSV, SbDV, and BWYV were the most prevalent viruses infecting chickpea plant in NW provinces of Iran.

\section{Introduction}

Chickpea (Cicer arietinum L.) Faba bean (Vicia faba L.) and lentil (Lens culinaris Medic) are the most important legume crops in Iran and widely cultivated in North West provinces of Lorestan, Kermanshah, West Azarbaijan and Hamedan (Anonymous, 2013). The seed of these crops is a good source of protein and calories for humans and play significant role in the farming system. The total area under chickpea cultivation in Iran is 472000 ha (Anonymous, 2013). Chickpea can be affected by a number of disease and pests, including viruses. Viral disease of economic 
importance have been reported to infect chickpea crop and causes considerable damage to the crop and economic losses to the farmers (Bos et al., 1988; Najar et al., 2000; Chen et al., 2011;Latham et al.,2004). Different biotic and a biotic agents can affect and cause yellowing symptoms on chickpea plants during its growing stages (Haobing et al., 2015). Various and common symptoms of yellowing, reduction in overall plant growth, dwarf stem, foliar bronzing and stunting, have been observed in chickpea diseased plants in farmers field (Najar et al., 2000; Makkouk, et al., 2002,2003; Kumari, et al., 2004, 2006a; Shahraeen et al., 2012; Heydari et al., 2013,2012). More than 12 viruses from different viral groups have been identified infecting chickpea naturally which include: Broad bean mottle virus (BBMV, genus Bromovirus, family Bromoviridae), Alfalfa mosaic virus (AMV, genus Alfamovirus, family Bromoviridae), Cucumber mosaic virus (CMV, genus Cucumovirus, family Bromoviridae; Jones and Coutts 1996), Pea seed-borne mosaic virus (PSbMV, genus Potyvirus, family Potyviridae, Chikpea chlorotic dwarf virus (CpCDV, genus Mastrevirus, family Geminiviridae), Bean yellow mosaic virus (BYMV, genus Potyvirus, family Potyviridae, Faba bean necrotice yellow vein virus (FbNYV, genus Nanovirus) (Franze et al.,199; Katul et al., 1993), pea enation mosaic virus-PEMV has previously been reported on pea (Kaiser et al., 1971,Makkouk et al., 2001b), and four Luteoviruses: Bean leaf roll virus (BLRV),Chickpea chlorotic stunt virusCpCSV, Beet western yellow virus (BWYV, genus Polerovirus, family Luteoviridae), Soybean dwarf virus (SbDV, genus Enamovirus, family Luteoviridae; Horn et al. 1993,1995; Katul et al. 1993; Makkouk et al., 1995,1997; Najar et al., 2000; Kaiser et al.,1972; Klein et al.,1991;Abraham et al.,2006). The Luteoviruses and FBNYV are transmitted by aphids in the persistent manner and CpCDV is transmitted by leafhopper. Four viruses are reported to be seed-born in chickpea namely BBMV, AMV, CMV and, probably PSbMV and AMV, CMV, BYMV and PSbMV are vectored by various aphids species in nonpersistent manner, whereas BBMV is transmitted by beetles species such as Apion spp and Sitona spp.(Jones and Coutts, 1996; Makkouk and kumari 1989,1995; Bos et al., 1988; Chen et al., 2010).There are also reports of chickpea naturally infected by tomato spotted wilt virus-TSWV, genus topspovirus (Thomas et al., 2004). Epidemiology of Tobacco streak virus-TSV (thrips transmitted) infecting chickpea was reported from Queensland, Australia and California, USA (Sharman et al., 2010; Kaiser et al., 1991).

Four species of bipartite begomoviruses (family-geminiviridae) recognized as causing yellow mosaic diseases-YMD of a number of legumes (mostly beans) in Southern Asia. These viruses are closely related and have distinct overlapping host ranges, but little evidence for interaction with viruses that infect other plants (Qazi et al., 2007). Chickpea plant with severe yellowing and tip wilting were observed to be infected by beet mosaic virus-BtMV (genus-potyvirus) (Kumari et al., 2010). A severe virus epidemic was reported on chickpea in Eastern Washington. Foliar chlorosis with distortion, reddening of leaf margins progressing to the entire leaf, pod and bud blight, and mosaic were specially common in chickpea. Incidence of symptomatic plants in chickpea field approached $100 \%$ (Klein et al., 1991). Diversity among the coat protein of luteoviruses associated with chickpea stunt disease has been reported from India, the result indicated that more than one luteovirus was present in chickpea stunt 
disease (Naidu et al., 1997). Chickpea filiform-CPF a new viral diseases of Cicer arietinum was detected in USA Cicer germ plasm collected at central Ferry, WA. The virus was serologically related to BYMV (Potyvirus) (Kaiser et al., 1988). Association of CpCDV-geminivirus and some luteoviruses have been reported with chickpea stunt disease in India, Pakistan, Syria, Turkey and Lebanon (Horne et al., 1995,1996).

In an intensive survey conducted during May-June, 2001, virus disease affecting chickpea (Cicer arietinum L.) and lentil (Lens culinaris Medik.) crops in five provinces (Qazvin, Kermanshah, Kurdistan, East Azarbaijan and West Azarbaijan) of Iran were investigated ( Makkouk et al., 2002,2003). A total of 15,106 chickpea, and 6,080 lentil samples were randomly collected; symptomatic samples, 2,017 from chickpea and 797 from lentil, were collected and tested, by tissue-blot immunoassay. Laboratory tests showed that, in the chickpea fields, Bean leaf roll virus (BLRV) and Chickpea chlorotic stunt virus (CpCSV) were most common, followed by Faba bean necrotic yellows virus (FBNYV) and Beet western yellow virus (BWYV). Other viruses detected at a low incidence in chickpea were pea enation mosaic virusPEMV, Alfalfa mosaic virus (AMV), Bean yellow mosaic virus (BYMV), Cucumber mosaic virus (CMV), Pea seed-borne mosaic virus (PSbMV), and Soybean dwarf virus (SbDV). In chickpea, around $64.7 \%$ of fields surveyed during 2001 had a virus disease incidence of $6 \%$ or higher, whereas in 2002 only $22.5 \%$ of the surveyed fields fell into this category. The overall incidence of virus (percentage of samples infected) was $11.1 \%$; CpCDV was the most common with an overall average of $4.3 \%$, followd by BLRV (4.1\%), FBNYV (1.1\%), BWYV (0.9\%), AMV (0.4\%), BYMV (0.2\%),
SbDV $(0.1 \%)$ and PSbMV (0.01\%); (Makkouk et al., 2002, 2003). Using the luteovirus-specific monoclonal antibody (MAb- B-2-5G4), a mixture of three MAbs (1-1G5, -3H4, and -4B12) to an Ethiopian (Eth) and Syrian (Sy) isolate of CpCSV, the presence of a serotype II isolate of CpCSV in two chickpea samples from Lorestan and Kermanshah provinces of Iran was reported (Bananej et al.,, 2010). CpCDV mastrovirus, BWYV luteovirus were reported to infect beet beta vulgaris in Iran ( Farzadfar et al., 2002).

During different surveys progressive symptoms of general yellowing in chickpea, lentil and faba bean crops have been observed in NW cool season legume growing provinces of Iran, and the association of viral agents with these symptoms have been reported (Shahraeen et al., 2013,2012; Heydari et al., 2013; Vafaei et al., 2008).

The main object of this survey was to determine the incidences of viruses associated with chickpea yellowing symptoms in the farmer field. Specially that of luteoviruses affecting and producing yellow like disease syndrome in chickpea crops in major food legume production areas of Iran, and to determine their association in yellowing, stunting, stem browning and bronzing symptoms of chickpea plant, incidence and relative importance with respect to economic impact on chickpea production in Iran.

\section{Materials and Methods}

\section{Field Visits and Sample Collections}

Field visits and collection of samples were conducted during May-June 2015 when the plants were at the flowering/pod setting stage. More than 10 field belonging to 
chickpea farmers were randomly selected. Each field was evaluated using a standard methodology (Makkouk et al., 2001,2002). the field evaluated during 2015 were in the following provinces (Location): Lorestan (Khoram Abad, Firouz Abad), Kermanshah (Ravansar, Azasara, Sara Rood, Faraman, Sahneh, Arkam, Karand, Harsine), Hamedan (Asad Abad, pefanj).The exact location of the field is shown in Table -1 and Fig1. Plant showing virus like disease symptoms in each field was determind by counting the percentage of pants exhibiting yellow symptoms at different, randomly chosen, location in the field, two types of sample were collected from each field; 2030 plants exhibiting typical and virus like yellowing symptoms were collected. Samples were placed in labeled plastic bags and brought on ice to the laboratory at Tehran. Testing for key viruses was done at the plant viruses research, IRIPP,Tehran.

A total of 170 chickpea samples with symptoms of yellowing suggestive of virus infection (foliar yellowing, chlorosis or reddening, stunting, growth reduction, phloem browning, narrow leaf (Fig-2), collected from over 10 chickpea fields were tested.

\section{Serological Assays}

All collected samples were tested for the presence of viruses using the tissue-blot immunoassay (TBIA), TAS and ACPindirect Elisa procedure using a battery of polyclonal MAb for FBNYV antibody. Rabbit polyclonal and monoclonals for CpCSV, BLRV (5G4), BLRV (6G4) was provided by Dr. Vetten lab. at JKI, Braunschweig, Germany, and polyclonal antisera for PSbMV, BWYV, SbDV and BLRV (family Luteoviridae) were provided by the virology laboratory of ICARDA, Aleppo, Syria. The TIBA procedure followed was that of Makkouk and Comeau (1994 ; Makkouk et al., 2003; Makkouk and Kumari,1996) with the following steps and washes in between: (1) cutting the plant samples (stems). With a razor blade and immediately blotting the cut surface on $\mathrm{NCM}$ or paper, (2) soaking the NCM/paper placed in a plastic container with a blocking agent, depending on the blocking reagent (3\% bovine serum albumin with PBSTween20 buffer) for $1 \mathrm{~h}$ at room temperature (3) soaking the NCM/paper with the virusantibody solution for $1 \mathrm{~h}$, (4) adding the antibody-alkaline phosphatase conjugate and leaving it to stand for $1 \mathrm{~h}$ and (5) adding the enzyme substrate mixture of nitro blue tetrazolium (NBT) and 5-bromo4-chloro-3-indolyl phosphate. The enzymatic reaction was terminated after 1530 min by rinsing the $\mathrm{NCM}$ /paper in distilled water, and air-drying it before reading. And also some selective samples are tested by triple (TAS) antibody sandwich enzyme-linked immuno sorbent assay (ELISA) technique described by Franz et al. 1996; respectively, using highbinding polystyrene plates (Greiner Bio-one $\mathrm{GmbH}$, Germany) and the buffers described by Clark and Adams 1977; In initial tests, samples were tested for the presence of Luteoviruses and FBNYV (nanoviruses), with the following steps and washes in between (3 times, each for $5 \mathrm{~min}$ ): (1) add IgG diluted in coating buffer incubate $3-4 \mathrm{~h}$ at $37 \dot{\mathrm{c}}$, (2) blocking ( $2 \%$ skim milk) incubate $1 \mathrm{~h}$ at room temperature, (3) add aliquots of test sample (extracted in sample extraction buffer) incubate overnight at $4 \dot{\mathrm{c}}$, (4) add Mab in appropriate dilution in conjugate buffer incubate for $2-4 \mathrm{~h}$ at $37 \dot{\mathrm{c}}$, (5) add RAM-ap in appropriate conjugate buffer incubate for 2 hour at 37ن (6) add aliquots of freshly prepared substrate incubate at room temperature for 30-60 min, or as long as necessary to obtain clear reactions. 


\section{Results and Discussion}

\section{Viral Disease Incidence in the Field}

During 2015, about 20-30 chickpea fields were surveyed. The disease incidence observed and collected samples in this study was mainly based on chickpea plant exhibiting specific yellowing symptoms. Most common symptoms were stunting, wilting, phloem browning, yellowing or reddening of the foliar leaves. Incidences of over $50 \%$ were observed and also reported in naturally infected experimental plots (Kermanshah experimental field station) in some years, although commercial losses have not been determined (Shahraeen et al., 2013).

\section{Virus Identification in the Laboratoty}

\section{Viruses Identified in Chickpea Showing Yellowing Symptoms}

To identify the luteoviruses affecting chickpea, infected samples were tested mainly by TIBA using NCM (Fig 3a,b) with the broad-spectrum monoclonal antibody 5G4 and further tested against specific monoclonal antibodies: two for BLRV (Mab. B-2-5G4, 4-6G6), and one for Soybean dwarf virus (SbDV).

Laboratory testing of 170 collected chickpea samples with yellowing symptoms indicated that overall incidence of viral infection was 75\%. Luteoviruses were the most common, followed by BLRV with polyclonal antibodies (26\%), Mab. B-2-5G4 (44\%) and 4-6G4 (52\%), BWYV(19\%),SbDV (33\%) and CpCSV (15\%). The incidence of FbNYVV ( nanovirus) was low less than $10 \%$. Mixed infection of a field with more than two or three viruses were common in many cultivation areas (Table 1, Fig 2).

The most common and widespread virus infection in single association detected from plant leaf samples was BLRV (Mab. 4-6G4) with $52 \%$ and the least common was FBNYVV with 7\% (Table-1). The study revealed the prevalent identity of four chickpea luteoviruses that are significantly associated with chickpea yellowing symptoms in chickpea fields in NW regions in Iran. The result obtained in this study showed that there was a substantial occurrence of viruses during 2015. Considerable variation of incidence and severity of virus symptoms among the districts were observed (Table 1).In all the provinces surveyed they exhibit virus like symptoms associated with yellowing with higher incidence and severity in Kermanshah districts compared to Lorestan and Hamadan districts.

Viral diseases infecting cool season food legumes in Iran specially the diseases inducing wilt of chickpea including pea leaf roll virus and the alternative hosts of viruses affecting food legumes in Iran has been reported by several workers ( Kaiser,1972; Kaiser and Danesh, 1971; Kaiser et al.,1972,1971,1993). Recently CpCSV, CMV,AMV and Broad bean mottle -BBMV bromoviruses has been reported from Kermanshah province; Heydari, et al.,2012,2013;Bananej et al.,2010). Natural occurrence of CpCDV was reported from sugar beet (beta vulgaris) and bean (P.vulgaris) in Iran (Farzadfar et al., 2002, 2008). Glycyrrhiza L. a common weed plant spp. in chickpea field in Iran showing a typical yellowing and stunting symptoms reacted positive to $\mathrm{SbDV}$ luteovirus in TIBA tests (Shahraeen et al.,2016).

Viral agents belonging to different groups are reported to infect cool season legumes. Luteo, mastro (CpCDV), CMV,AMV, BBMV (Bromo), and BYMV, PSbMV potyviruses are of main viral agents although there are still viral agents associated with chickpea stunt virus and 
legume yellow diseases and BWYV group to be differentiated and characterized. RNA sequences have been determined for some chickpea or lentil isolates, including the complete sequence of one isolate of the proposed species chickpea chlorotic stunt virus (CpCSV), partial sequence of two
BWYV-like isolate, and sequence of one isolate each of proposed species chickpea stunt disease associated virus (CpSDaV), chickpea yellows virus (CpYV) and lentil stunt virus (LStV). (Chen et al., 2011; Horne et al., 1995,1993).

Fig.1 Chickpea Plants in the Field with Yellowing Symptoms and Virus Infection
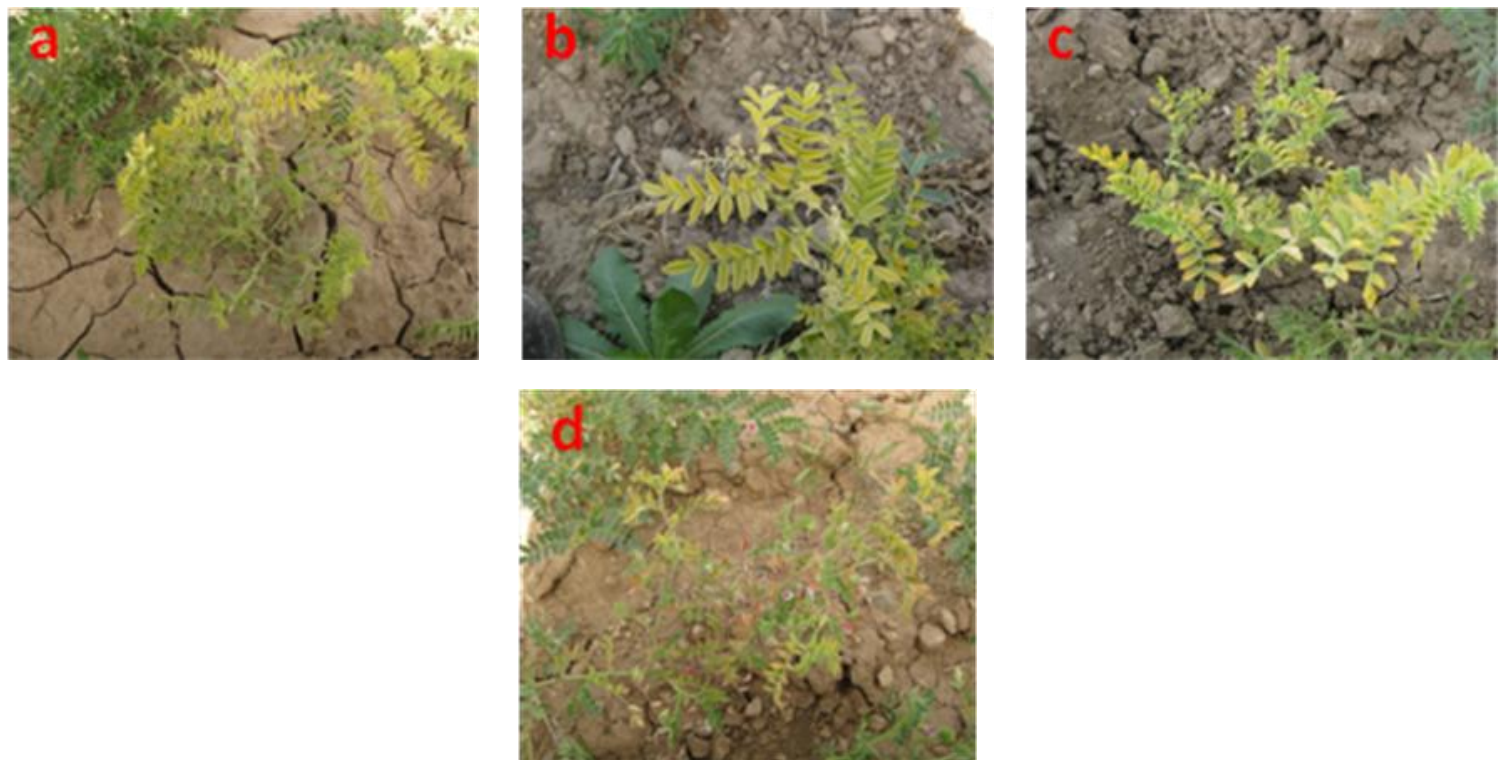

a-general yellowing,b-yellowing and tip wilting, c- yellowing and narrow leaves, d- yellowing and reddening of leaves

Fig.2 a,b =Detection of CpCSV-Luteoviruses in print of Cross-sections of Infected Chickpea Plant (purple/dark) and Healthy Plant (Green), using Tissue-blot Immunoassay (TIBA). This

Test used Raw Antiserum Dilution of 1:500 and Goat Anti Rabbit IgG alkalin phosphatase Conjugate Dilution of 1:1000
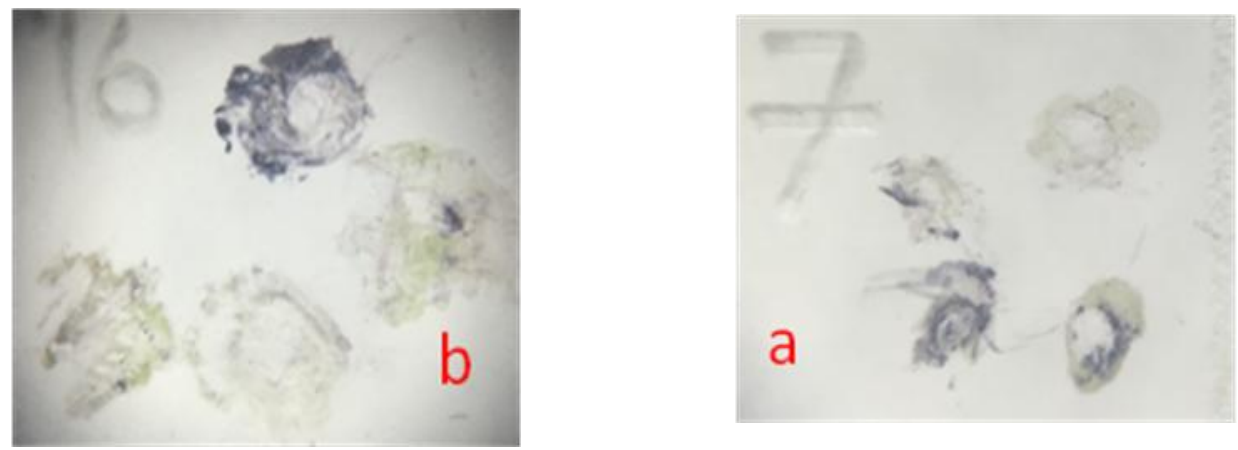
Int.J.Curr.Res.Aca.Rev.2016; 4(4): 98-109

Table.1 Homologous and Heterologous Reactions of Monoclonal and Polyclonal Antibodies used in this Study. Tissue-blot Immunoassay (TIBA) and ELISA Reactions of Luteoviridae:

Chickpea Chlorotic Stunt Virus (CpCSV), Beet Western Yellow Virus (BWYV), Bean Leaf Roll

Virus Poly and Mab (BLRV-b-2-5G4, and 4-6G4 ), Soybean Dwarf Virus (SbDV) and Faba

Bean Necrotic Yellow Vein Virus (FNYVV-nanovirus)

\begin{tabular}{|c|c|c|c|c|c|c|c|c|c|c|c|c|c|c|c|c|}
\hline \multirow{4}{*}{$\begin{array}{c}\begin{array}{c}\text { Name of } \\
\text { chickpea } \\
\text { fields surveyed }\end{array} \\
\text { Lorestan }\end{array}$} & \multirow{4}{*}{$\begin{array}{c}\text { Sample } \\
\text { batch } \\
\text { number }\end{array}$} & \multicolumn{15}{|c|}{ Virus species } \\
\hline & & \multirow{2}{*}{\multicolumn{2}{|c|}{$\begin{array}{c}\text { CpCSV } \\
\text { I }\end{array}$}} & \multirow{2}{*}{\multicolumn{2}{|c|}{$\begin{array}{c}\text { FbNYV } \\
\text { V } \\
\text { II }\end{array}$}} & \multirow{2}{*}{\multicolumn{2}{|c|}{$\begin{array}{c}\text { BWYV } \\
\text { III }\end{array}$}} & \multicolumn{6}{|c|}{ BLRV } & \multirow{2}{*}{\multicolumn{2}{|c|}{$\begin{array}{r}\text { SbDV } \\
\text { VII }\end{array}$}} & \multirow{3}{*}{$\begin{array}{l}\text { Mix infection } \\
\text { I,II,III,IV,V, } \\
\text { VI,VII }\end{array}$} \\
\hline & & & & & & & & \multicolumn{2}{|c|}{$\begin{array}{l}\text { (6G4) } \\
\text { IV }\end{array}$} & \multicolumn{2}{|c|}{$\begin{array}{c}\text { (5G4) } \\
\text { V }\end{array}$} & \multicolumn{2}{|c|}{$\begin{array}{l}\text { polyclonal } \\
\text { VI }\end{array}$} & & & \\
\hline & & $\mathbf{E}$ & $\mathbf{T}^{*}$ & $\mathbf{E}$ & $\mathbf{T}$ & $\mathbf{E}$ & $\mathbf{T}$ & $\mathbf{E}$ & $\mathbf{T}$ & $\mathbf{E}$ & $\mathbf{T}$ & $\mathbf{E}$ & $\mathbf{T}$ & $\mathbf{E}$ & $\mathbf{T}$ & \\
\hline Nour Abad & 1 & - & - & - & & - & & & $4+$ & & $4+$ & + & $1+$ & & $2+$ & IV,V, VI,VII \\
\hline Firouz Abad & 4 & - & - & - & & - & & & $3+$ & & $4+$ & + & - & & $3+$ & IV,V, VI,VII \\
\hline $\begin{array}{l}\text { Aleshtar } \\
\text { (junction) }\end{array}$ & 5 & - & - & - & & $4+$ & & & $4+$ & & $4+$ & + & - & & - & III,IV,V, VI \\
\hline Takane & 6 & - & - & - & & + & & & $4+$ & & $4+$ & + & - & & - & III,IV,V \\
\hline $\begin{array}{l}\text { Khoram Abad } \\
\text { (bisheh) }\end{array}$ & 8 & - & - & - & & - & & & $4+$ & & $1+$ & - & - & & $4+$ & $\mathrm{IV}, \mathrm{V}, \mathrm{VII}$ \\
\hline Sub total & & - & - & - & & 8 & & & 19 & & 17 & 16 & 1 & & 9 & \\
\hline \multicolumn{17}{|l|}{ Kermanshah } \\
\hline $\begin{array}{l}\text { Ravansar } \\
\text { (ros 2) }\end{array}$ & 10 & - & - & + & & - & & & $3+$ & & $4+$ & - & - & & $4+$ & II,IV,V,VII \\
\hline Azasara & 11 & - & - & - & & + & & & $2+$ & & $1+$ & - & - & & $4+$ & III,IV,V,VII \\
\hline Sara roud 3 & 12 & - & - & - & & - & & & - & & $2+$ & - & $4+$ & & - & $\mathrm{V}, \mathrm{VI}$ \\
\hline Karsazan 2 & 13 & - & $2+$ & - & & - & & & $4+$ & & $4+$ & + & $1+$ & & $1+$ & $\mathrm{I}, \mathrm{IV}, \mathrm{V}, \mathrm{VI}, \mathrm{VII}$ \\
\hline $\begin{array}{c}\text { Ravansar } \\
\text { (Baghe rezvan) }\end{array}$ & 14 & + & $2+$ & - & & - & & & $1+$ & & $4+$ & + & $2+$ & & $4+$ & I,IV,V, VI,VII \\
\hline $\begin{array}{l}\text { Eslam Abad } \\
\text { (4 zebar) }\end{array}$ & 15 & - & - & - & & - & & & $2+$ & & - & - & $4+$ & & $1+$ & IV, VI,VII \\
\hline Sahneh 1 & 16 & - & $1+$ & - & & - & & & $1+$ & & $4+$ & - & - & & - & $\mathrm{I}, \mathrm{IV}, \mathrm{V}$ \\
\hline Harsin & 17 & - & - & - & & - & & & - & & - & - & - & & - & - \\
\hline Sahneh & 18 & - & $4+$ & - & & - & & & $4+$ & & - & - & $4+$ & & $4+$ & I,IV,VI,VII \\
\hline $\begin{array}{c}\text { Faraman } \\
\text { (Koron sefliy) }\end{array}$ & 19 & - & $2+$ & - & & - & & & $1+$ & & $4+$ & - & $1+$ & & $2+$ & $\mathrm{I}, \mathrm{IV}, \mathrm{V}, \mathrm{VI}, \mathrm{VII}$ \\
\hline $\begin{array}{l}\text { Sar Aroud } \\
\text { (Asir shah) }\end{array}$ & 20 & + & $2+$ & - & & - & & & $2+$ & & - & + & - & & - & $\mathrm{I}, \mathrm{IV}$ \\
\hline $\begin{array}{l}\text { Sararoud } \\
\text { (Adel 1) }\end{array}$ & 21 & + & - & + & & - & & & $4+$ & & $4+$ & - & $2+$ & & $2+$ & $\begin{array}{l}\text { I,II,IV,V, } \\
\text { VI,VII }\end{array}$ \\
\hline Harsin 2 & 27 & - & $4+$ & - & & + & & & $2+$ & & $4+$ & + & $4+$ & & $4+$ & $\begin{array}{l}\text { I,III,IV,V, } \\
\text { VI,VII }\end{array}$ \\
\hline Tange Mersad & 29 & - & - & - & & + & & & $4+$ & & - & + & - & & - & III,IV \\
\hline $\begin{array}{l}\text { Eslam Abad } \\
\text { (Aliabad) }\end{array}$ & 30 & - & - & - & & - & & & $2+$ & & - & - & - & & $1+$ & IV,VII \\
\hline $\begin{array}{c}\text { Karand } \\
\text { (Toudeh ali) }\end{array}$ & 31 & - & - & - & & - & & & $1+$ & & $1+$ & + & $2+$ & & - & IV,V, VI,VII \\
\hline Kamyaran 1 & 32 & - & $1+$ & + & & - & & & $4+$ & & $4+$ & + & - & & $1+$ & $\mathrm{I}, \mathrm{II}, \mathrm{IV}, \mathrm{V}, \mathrm{VII}$ \\
\hline $\begin{array}{c}\text { Harsin } \\
\text { (500 rasi) }\end{array}$ & 33 & - & - & - & & + & & & $4+$ & & - & - & - & & - & III,IV \\
\hline Kangavar & 34 & - & $2+$ & - & & - & & & $4+$ & & $1+$ & - & $2+$ & & $4+$ & $\mathrm{I}, \mathrm{IV}, \mathrm{V}, \mathrm{VI}, \mathrm{VII}$ \\
\hline Soleyman Abad & 35 & - & $2+$ & - & & + & & & $4+$ & & $1+$ & + & $4+$ & & $2+$ & I,III,IV,V, \\
\hline
\end{tabular}


Int.J.Curr.Res.Aca.Rev.2016; 4(4): 98-109

\begin{tabular}{|c|c|c|c|c|c|c|c|c|c|c|c|}
\hline & & & & & & & & & & & VI,VII \\
\hline $\begin{array}{c}\text { Eslam Abad } \\
\text { (Houme 2) }\end{array}$ & 36 & - & - & - & + & $1+$ & - & - & $1+$ & - & III,IV,VI \\
\hline Ravansar 1 & 37 & - & $3+$ & - & - & $3+$ & $4+$ & + & $1+$ & $2+$ & $\mathrm{IV}, \mathrm{V}, \mathrm{VI}$ \\
\hline $\begin{array}{c}\text { Eslam Abad } \\
\text { (Houme 1) }\end{array}$ & 38 & - & - & - & - & $4+$ & $4+$ & - & - & - & IV,V \\
\hline $\begin{array}{c}\text { Sar Aroud } \\
\text { (adel 2) }\end{array}$ & 39 & - & - & - & - & $4+$ & $2+$ & - & $1+$ & $3+$ & IV,V, VI,VII \\
\hline $\begin{array}{l}\text { SarAroud } \\
\text { (A1) }\end{array}$ & 40 & - & - & - & - & $1+$ & $4+$ & - & $4+$ & - & IV,V, VI,VII \\
\hline Sub total & & 12 & 25 & 12 & 24 & 62 & 52 & 36 & 37 & 39 & \\
\hline \multicolumn{12}{|l|}{ Hamedan } \\
\hline Asad Abad 1 & 25 & - & - & - & - & $4+$ & $4+$ & + & $2+$ & - & IV,V, VI \\
\hline Asad Abad 2 & 26 & - & - & - & - & - & - & - & - & $4+$ & VII \\
\hline Pefanj & 28 & + & $4+$ & - & - & $4+$ & $2+$ & - & $4+$ & $4+$ & $\mathrm{I}, \mathrm{IV}, \mathrm{V}, \mathrm{VI}, \mathrm{VII}$ \\
\hline Sub total & & & 4 & & & 8 & 6 & & 6 & 8 & \\
\hline Total & & & $\begin{array}{c}29 \\
(17 \% \\
)\end{array}$ & $\begin{array}{l}12 \\
(7 \\
\%) \\
\end{array}$ & $\begin{array}{c}32 \\
(19 \\
\%) \\
\end{array}$ & $\begin{array}{c}89 \\
(52 \%)\end{array}$ & $\begin{array}{c}75 \\
(44 \%)\end{array}$ & & $\begin{array}{c}44 \\
(26 \%)\end{array}$ & $\begin{array}{c}56 \\
(33 \%)\end{array}$ & \\
\hline
\end{tabular}

$*=$ No of infected samples was mainly determined on basis of TIBA assay, except for FBNYVV

$\mathrm{E}=$ Elisa test, $\mathrm{T}=$ Tissue-blot immunoassay $(\mathrm{TIBA}),+=$ positive reaction, $-\mathbf{=}$ no reaction

$(1,2,3,4+)=$ Positive number of plants showing positive reaction on blotted NCM

Fig.3 Percentage of Virus Identification on Chickpea Fields using Homologous and Heterologous Reactions of Monoclonal and Polyclonal Antibodies

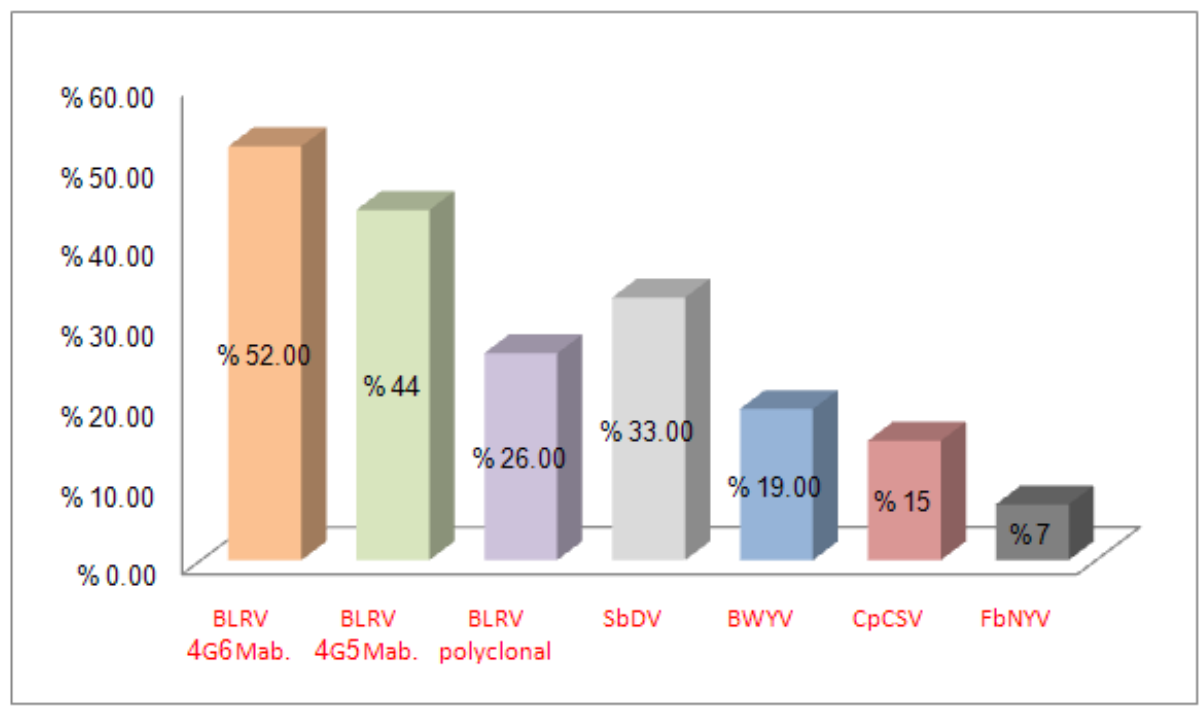

The epidemiology of virus diseases of chickpea including legume yellows (LYV) was studied in California. The incidence of viruses in field trail at Davis, Salinas and the Zan Joaquin Vally was 60-100 \% (BosquePerez and Buddenhagen, 1990).

Natural infection by mastreviruses was investigated in chickpea and other dicotyledonous crops and weeds in grain production area of Queensland and NSW Australia. Among 42 isolates from 41 chickpea plants with symptoms of foliar chlorosis or reddening, stunting and usually phloem browning, one was typical tobacco yellow dwarf virus (TYDV) and the others were three recently distinguished strains of chickpea chlorosis virus strain A,B and one 
Int.J.Curr.Res.Aca.Rev.2016; 4(4): 98-109

chickpea read leaf virus (Schwinghamer et al., 2010).

However, the present study did not carry out a wide coverage to other chickpea growing districts in different region due to limited resources. It is important to conduct such a study in other region to understand the distribution, prevalence and molecular characterization of mainly chickpea yellows luteoviruses, determining the diversity, variability since it is essential in any breeding and control strategy.

\section{Conclusion}

Viral agents belonging to different groups are associated with chickpea yellowing diseases. These viruses pose an economic threat to chickpea cultivation. Luteovirus species have most often been distinguished by serological tests including ELISA and tissue blot immunoassay (TBIA). There is an element of doubt in these identifications, however, because all legume (Fabaceae) infecting luteoviruses show some degree of serological relatedness. Monoclonal antibodies (Mab) supported by nucleic acid based technique including reverse transcription polymerase chine reaction (RTPCR) and membrane hybridization are reliable and valuable tests for processing large numbers of samples. Characterization of each virus to molecular level and the evolutionary studies will help in developing proper control strategies.

\section{References}

Abraham, A.D., Menzel, W., Lesemann, D.E, Varrelmann, M., Vetten, H.J. 2006. Chickpea chlorotic stunt virus : A new polerovirus infecting coolseason food legumes in Ethiopia. Phytopathol., 96(5): 437-446.
Anonymous. 2013. Cultivated crop production statistics, office of planning and economic studies, Ministry of agriculture, lslamic republic of Iran. P 212.

Bananej, K., Vahdat, A., Menzel, W., Vetten, H.J. 2010. Serological and molecular identification of chickpea chlorotic stunt virus from chickpea in Iran. Plant Dis., 94: 788.

Bos, L., Hampton, R.O., Makkouk,. K.M. 1998. Viruses and viral disease of pea, Lentil, faba bean and chickpea. In: Summerfield R. J. (ed.): World crops: cool season food legumes, pp 591615. Kluwer Academic Publishers, Dordrecht, The Netherlands.

Bosque-Perez, N.A., Buddenhagen, I.W. 1990. Studies on epidemiology of virus diseases of chickpea in California. Plant Dis., 74: 372-378.

Chen, W., Sharma, H.C., Muehlbaur, F.J. 2011. Compendium of chickpea and lentil diseases and pests. American Phytopathological Society-APS, Part -1 : Diseases caused by viruses. pp 231.

Farzadfar, Sh., Pourrahim, R., Golnaraghi, A.R., Ahoonmanesh, A. 2008. PCR detection and partial molecular characterization of chickpea chlorotic dwarf virus in naturally infected sugar beet plants in Iran. J. Plant Pathol., 90(2): 247-251.

Farzadfar, Sh., Pourrahim, R.,Golnaraghi, A.R., Shahraeenm N., Makkouk, K.M. 2002. First report of suger beet and bean as natural hosts of chickpea chlorotic dwarf virus in Iran. Plant Pathol., 51: 715.

Franz, A., Makkouk, K.M., Katul, L., Vetten, H.J. 1996. Monoclonal antibodies for the detection and differentiation of faba bean necrotic yellow virus isolates. Annals of App. Biol., 128: 255-268. 
Int.J.Curr.Res.Aca.Rev.2016; 4(4): 98-109

Haobing, $\quad$ L.I., $\quad$ Rodda, M., Gnanasambandam, A., Aftab, M.,Redden, R., Hobson, K., Rosewarne, G., Materne, M., Kaur, S., Slater, T.A. 2015. Breeding for biotic stress resistance in chickpea: progress and prospects. Euphytica, 204: 257288.

Heydari, F., Shahraeen, N., Maleki, M. 2013. Serological and molecular detection of two viruses from bromoviridae family infecting chickpea plant. The $8^{\mathrm{TH}}$ biotechnology symposium and fourth national biosecurity symposium of IR of Iran, 6-8 July,Tehran, Iran.

Heydari, F., Shahraeen, N., Maleki, M. 2012. Biological, serological and molecular identification of cucumber mosaic virus from chickpea fields in Kermanshah provience. Appl. Plant Protection (Iranian), 1(3): 212-220.

Horn, N.M., Makkouk, K.M., Kumari, S.G., van den Heuvel, J.F.J.M., Reddy, D.V.R. 1995. Survey of chickpea (Cicer arietinum $L$.) for chickpea stunt disease and associated viruses in Syria, Turkey and Lebanon. Phytopath Medit, 34: 192-198.

Horn, N.M., Reddy, S.V., Heuvel van den, J.F.J.M., Reddy, D.V.R. 1996. Survey of chickpea (Cicer arietinum L.) for Chickpea stunt and associated viruses in India. Plant Dis., 80: 286290.

Horn, N.M., Reddy, S.V., Roberts, I.M., Reddy, D.V.R. 1993. Chickpea chlorotic dwarf, a new leafhoppertransmitted geminivirus of chickpea in India. Ann. Appl. Biol., 122: 467-479.

Jones, R.A.C., Coutts, B.A. 1996. Alfalfa mosaic and Cucumber mosaic virus infection in chickpea and lentil: Incidence and seed transmission. Ann. Appl. Biol., 129: 491-506.
Kaiser, W.J. 1972. Diseases of food legumes caused by Pea leaf roll virus in Iran.FAO Plant Protection Bull., 20(6): 127-133.

Kaiser, W.J., Danesh, D. 1971. Etiology of virus induced wilt of Cicer arietinum. Phytopothol., 61(5): 453-457.

Kaiser, W.J., Danesh, D., Okhovat, M., Mossahebi, G. 1972.Virus diseases of pulses crop in Iran. Tehran university publication, Karaj, Iran. p10-14.

Kaiser, W.J., Klein, R.E., Larsen, R.C., Wyatt, S.J. 1993. Chickpea wilt incited by pea streak Carlavirus. Plant Dis., 77: 922-926.

Kaiser, W.J., Mossahebi, G.M., Okhovat, M. 1971. Alternate hosts of viruses affecting food legumes in Iran. Iranian J. P1. Pathol., 7: 25.

Kaizer, W.J.,Wyatt, S.D., Hannan, R.M., Coddy, Y. 1988. Chickpea filiform, a new viral diseases of Cicer arietinum. Plant Dis., 72: 70-74.

Katul, L., Vetten, H.J., Maiss, E., Makkouk, K.M., Lesemann, D.E., Casper, R. 1993. Characteristics and serology of virus-like particles associated with faba bean necrotic yellows. Ann. Appl. Biol., 123: 629-647.

Klein, R.E., Larsen, R.C., Kaiser, W.J. 1991. Virus epidemic of grain legumes in Eastern Washington. Plant Dis., 75: 1186.

Klein, R.E., Larsen, R.C., Kaiser, W.J. 1991. Virus epidemic of grain legumes in Eastern Washington. Plant Dis., 75: 1186.

Kumari, S.G., Najar, A., Loh, M.H., Attar, H., Vetten, H.J. 2010. First report of beet mosaic virus infecting chickpea (Cicer arietinum) in Tunisia. Plant Dis., 94(8): 1068.

Kumari, S.G., Rodoni, B., Loh, M., Makkouk, K.M., Freemanand, M., van Leur, J. 2006a. Distribution, identification and characterization of 
Luteoviruses affecting food legumes in Asia and North Africa. In: Proceeding of 12th Mediterranean Phytopathological Congress, 11-15 June 2006, Rhodes Island, Greece, 412-416.

Kumari, S.G., Rodoni, M.F., Makkouk, K.M., Freeman, A., van Leur, J. 2004. Distribution, identification and characterization of Luteoviruses affecting food legumes in Asia and North Africa In: Proceeding of $12^{\text {th }}$ Mediterranean Phytopathological Congress, 11-15 June, Rhode Island, Greece, 412-416.

Latham, J.J., Jones, R.A.C., Coutts, B.A. 2004. Yield losses caused by virus infection in four combination of nonpersistently aphid-transmitted virus and cool-season crop legume. Australian J. Experimental Agri., 44: 57-63.

Makkouk, K.M., Comeau,A. 1994. Evaluation of various methods for the detection of barley yellow dwarf virus by the tissue-blot immunoassay and its use for virus detection in cereals inoculated at different growth stages. European J. Plant Pathol., 100: 7180.

Makkouk, K.M., Kumari, S.G., Shahraeen, N., Fazali, Y., Farzadfar, S., Ghotbi, T., Mansouri, R.A. 2003. Identification and seasonal variation of viral disease of chickpea and lentil in Iran. J. Plant Dis. Protection, 110(2): 157-169.

Makkouk, K.M., Kumari, S.G. 1989. Apion arrongans, a weevil vector of broad bean mottle virus. Fabis Newsl., 25: 26-27.

Makkouk, K.M., Kumari, S.G. 1995. Transmission of broad bean stain comovirus and broad bean mottle bromovirus by weevils in Syria. Z. Pflchutz, 102: 136-139.
Makkouk, K.M., Kumari, S.G. 1996. Detection of ten viruses by the Tissueblot immunoassay (TBIA). Arab $J$. P1. Protc., 14: 3-9.

Makkouk, K.M., Dafalla, G., Hussein, M., Kumari, S.G. 1995. The natural occurrence of chickpea chlorotic $d$ warf geminivirus in chickpea and faba bean in the Sudan. J. Phytopath., 143: 465-466.

Makkouk, K.M., Damsteegt, V., Johnstone, G.R., Katul, L., Lesemann, D.E., Kumari, S.G.1997. Identification and some properties of soybean dwarf luteovirus affecting lentil inSyria. Phytopath. Medit., 36: 135-144.

Makkouk, K.M., Fazlali, Y., Kumari, S.G., Farzadfar, S. 2002. First record of Beet western yellows, Chickpea chlorotic dwarf, Faba bean necrotic yellow and Soybean dwarf viruses affecting chickpea and lentil crops in Iran. P1. Path., 51: 387.

Makkouk, K.M., Kumari, S.G., Lesemann, D.E. 2001b. First record of Pea enation mosaic virus naturally infecting chickpea and grass pea crops in Syria. P1. Dis., 85: 1032.

Naidu, R.A., Mayo, M.A., Reddy, S.V., Jolly, C.A., Torrance, L. 1997. Diversity among the coat protein of Luteoviruses associated with chickpea stunt disease in India. Ann. App. Biol., 130: 37-47.

Najar, A., Makkouk, K.M., Boudhir, H., Kumari, S.G., Zarouk, R., Bessai, R., Othman, B.F. 2000. Viral diseases of cultivated legume and cereal crops in Tunisia. Phytopath. Medit., 39: 423432.

Qazi, J., Ilyas, M., Mansor, S., Briddon, W. 2007. Legume yellow mosaic:genetically isolated begomoviruses. Mol. Plant Pathol., 8(4): 343-348. 
Schwinghamer, M.W., Thomas, J.E., Schilg, M.A., Parry, J.N., Dann, E.K., Moore, K.J., Kumari, S.G. 2010.Mastreviruses in chickpea (Cicer arietinum) and other dicotyledonous crops and weeds in Queenland and northern New South Wals, Australia. Australasian Plant Pathol., 39: 551561.

Shahraeen, N., Azadbakhat, N., Yunesi, H. 2012. Reports of viral diseases of cool season legumes in Iran and control managements strategies. In abstracts of the $4^{\text {th }}$ Iranian Pulses crop symposium,8-9 Feb.2012, Arak, Iran. Sharman, M., Persly, D.M., Thomas, J.E. 2010. Epidemiology of tobacco streak virus in Queensland, Australia. Proceeding of the $1^{\text {st }}$ Australian summer grains conference, Gold Coast, Australia, $21^{\text {st }}-24^{\text {th }}$ June 2010.

Vafaei, S.H., Azadbakht, N., Shahraeen, N., Haji, M. 2008. Survey for virus diseases of chickpea and lentil in province of Lorestan. $18^{\text {th }}$ Iranian Plant Protection Congress, 24-27 Aug. Hamadan, Iran.

\section{How to cite this article:}

Shahraeen Nooh, Ghotbi Tabassom, Haji Yousef Tara, Azadbakht Nader and Bananej Kaveh. 2016. An Overview of Viral Disease on Chickpea and Impact on Chickpea Production in Iran. Int.J.Curr.Res.Aca.Rev.4(4): 98-109. doi: http://dx.doi.org/10.20546/ijcrar.2016.404.012 